\title{
MATTER IN PLACE
}

It should be obvious to most readers that the title for this special issue on material culture which was also the title of a symposium in November 2007, was inspired by a now classic line from Professor Dame Mary Douglas' celebrated book Purity \& Danger. In her insightful analysis of the ways in which pollution and taboo are culturally constructed and social structured, Douglas penned the well cited phrase 'Dirt is matter out of place' (1966:44).

Undoubtedly, this definition has come to stand as shorthand for a plethora of research on waste, rubbish and the notion of social defilement. In attempting to revalidate the significance of local issues in material culture studies, there might be some mileage in turning this maxim on its head - to suggest, with only partial facetiousness, that 'place is matter out of dirt'.

Indeed, our Matter in Place discussion forum was held in the same year of Mary's passing. With this and several other 'Douglasesque' pearls of wisdom fresh in the minds of many people around the world during the months after her death, the idea of commemorating as well as appropriating the thinking of someone so influential to the overall ethos of material culture studies seemed to make sense. Our ambition was really quite simple - to highlight some antipodean examples of the work being done in this field of study. The matter of our analysis was not dirt, rubbish or waste, however. Instead, we wanted to emphasise more generally the tangible manifestations of the local in an ever globalising world - the material significances of 'sites' if you will (Hutton 1944; Friedman 1994; Mintz 2000).

Consequently, we selected Aotearoa/South Pacific Forum for Social Matters as an appropriate subtitle for an interdisciplinary event that also highlighted the development of 'MATTER', an imminent research centre in the School of Visual \& Material Culture, Massey University. We invited guest speakers with various interests in material culture studies to help contextualise the current state of research and teaching in this area within Aotearoa/New Zealand and 
the Pacific. Not only were the research profiles of participating scholars relevant to general concerns about material culture in the Pacific, they were also able to speak to wider theoretical and methodological developments in their respective areas. Equally, we wished to address the growing trans-disciplinary crossovers and collaborations between pedagogy, creative art, museum curation, community participation and social issues. Some of the contributions to the forum feature in this issue, along with additional recruits.

Although well-established as a sub-field of anthropology, archaeology and history in Britain and North America, material culture studies is still a relatively recent area of research in New Zealand. As a result, the Matter in Place forum was a first attempt to overtly and comprehensively begin to define this field on these shores; one that hoped to outline a unique interdisciplinary niche which would explicitly bring art and design into the equation, perhaps shaping a more open terrain for material culture studies in the southern hemisphere.

Through a range of disciplinary perspectives, the following papers and book reviews respond to this goal in a variety of innovative and insightful ways. The issue moves from the very concrete, complex practices of museum curation, through to the troubled waters of contested land ownership claims; from considerations of motifs and iconicity across island identities to multisensory experiences of particular submerged seascapes; from how archaeological knowledge is categorised and transmitted to a mobile archive of travel documents which deal with both place and the placeless.

The issue begins with a careful analysis by Huhana Smith of the principles and practices of Maori curation at New Zealand's national museum, Te Papa Tongarewa. As a curator at this institution herself, Smith is ideally located to examine how curators 'actively engage in research processes that re-enhance the inter-relationships between peoples and their cultural material. Her paper follows recent calls to examine the complex relationships that exist between indigenous cultures and colonial states when it comes to the complications surrounding exhibitionary complexes and the politics of display (Pearce 1995). Following the 'mana taonga' principle, the paper outlines and shows through three different case studies a toolkit containing 'a range of different types of aims, theory, methods and resources that may be employed by curators when executing research initiatives around taonga Maori'.

Marama Muru-Lanning's piece 'River Ownership: Inalienable Taonga and Impartible Tupuna Awa' also deals with the taonga principle, this time in terms of the contrasts that exist between Maori views of ownership and Pakeha defi- 
nitions based on the Crown's legacy of land purchases and appropriation. Her in-depth ethnographic study addresses the differing cultural understandings of the Treaty of Waitangi when it comes to interpreting what it means to be able to 'legally' own what might otherwise be seen as inalienable parts of an intangible cultural heritage. Muru-Lanning's paper on the materiality of water rights access and management issues might well be aligned, although tangentially, with Gaston Bachelard's musings (1942 [1983]) on the fluidity of 'dreamscapes', at least in terms of thinking about how certain collective visions to regain indigenous control over resource use are formulated.

Wendy Cowling follows with a detailed account of how material forms - in this case a decorative motif on cloth - are taken into the New Zealand public domain as a representation of Pacific/New Zealand identity. By providing a brief ethnographic contextualisation within the contemporary Tongan and New Zealand contexts, Cowling's paper offers an interesting historical discussion of the particular Lapita motif's enduring iconicity. As she notes, 'An ancient motif [...] has become commoditised and accepted as a popular signifier of the country's Oceanic identity. This motif has been given a new identity and name, because of an association of ideas linked to the remembered sensory experience of seeing, wearing and smelling a non-indigenous perfumed flower'. Lapita has thus become what Henri Bergson (1911) might have called a mnemonic signifier of 'islandness' for fashion designers, wearable art displays, as well as the ubiquitous tourist industry (Burn and Kahn 2005). Cowling also suggests that taking into account regional, historical and environmental factors in the construction of such motifs may offer fruitful avenues for future research.

The importance of the multi-sensory experience is taken up by Kumi Kato, who focuses on the ama free-divers in Japan. Analysing the distinct breathing sounds they produce, she suggests that sound is one of the major factors in constructing a particular cultural landscape. She then links this soundscape to the ethics and spiritual values of such a subsistence community. Kato argues that this soundscape provides a holistic framework to reconcile the humannature divide and to know the world. Exploring how cultural landscapes are composed and understanding the various forms of human-environment interactions are vital processes for the promotion of both cultural and biological diversity and their sustainability. It opens up a highly pertinent discussion on diversity in human-nature connectivity and its cultural distinctiveness (Ingold 2000). While there has been considerable research in this area, few studies deal with a marine context. The phenomenological subject matter treated by Kato's article is therefore valuable both conceptually and culturally. 
The next piece explores knowledge and its narrative categories in New Georgia, Solomon Islands. Tim Thomas discusses topogenetic forms, or forms associated with the recitation of an ordered sequence of place-names, as a means of categorising and transmitting social knowledge. He makes reference to Hocart's significant historical work and the research carried out more recently by the New Georgia Archaeological Survey (NGAS). Previously such forms were seen as a post-colonial ideological imposition on the landscape. But Thomas shows instead that, through archaeological dating of ancestral sites and the associated genealogical shrines and charms, the narratives have their own distinct historical content. He uses examples from his own fieldwork and the work of the NGAS to construct a compelling argument for paying closer attention to the topogenic dimensions of social relations. As he concludes, with a certain Russellian (1927) undertone, there is a mnemonic process in practical embodied engagements with things and places which is about the existential construction of narrative.

Finally, Matthew Henry brings us back to Aotearoa/New Zealand by focusing on one of the archetypal artefacts of mobility and modernity - the passport. Taking what is largely an historical perspective rooted in colonial New Zealand, he examines the 'hidden genealogies and geographical imaginations' of travelling documents. Henry focuses on the network embraced by and created for the traveller, arguing that rather than annihilating place, travel documents 'entangle the traveller in complex relationships of placeness and placenessless which have long been based on the biopolitical geographies of threat and risk'. While much of the material culture associated with travel is ephemeral in nature, the passport is tangible, durable and inscribable. In balancing concerns for the local and the global which this special issue has sought to address, Henry's paper resonates with Benedict Anderson's (1983) theories about the ways in which hegemonic state discourses are imagined and normativised, materialised and erased.

The issue concludes with six book reviews which explore recent volumes in the field of material culture studies, including both single authored and edited collections as well as works by New Zealand and international scholars. As Ian Wedde demonstrates in his review, these contributions can themselves be seen as objects of material culture - a type of reflexive matter; they are sites of intellectual construction that can be analysed on multiple levels to tell us something about the development or collapse of certain academic canons. Hence, our desire to include an extensive range of book reviews not only attests to the growing literature in the field but also illustrates the diversity of new ways of thinking about material culture across a range of sites, topics and approaches. 
So since dirt is matter out of place, and as we might now usefully acknowledge 'place is matter out of dirt', it is worth reiterating that the focus here is to emphasise the significance of material culture studies within the Pacific. With this special issue we wish to identify the place of antipodean material culture studies within this ever-expanding field. From their various vantage points, the aforementioned articles describe the complex relationships between things and location, materiality and sites. In other words, the present collection aims to demonstrate the myriad ways in which place itself becomes 'matter in place'.

In so doing, our contributors and book reviewers reveal that objects are not only much more than they appear to be, they are also now understood as much more than they once were: they are reifications of knowledge systems, objectifications of relationships and materialisations of people's engagements with their everyday life-worlds (Graves-Brown 2000; Miller 1998; Prown 1983). In uncovering the strategies that communities employ to materialise their relations, desires and values, this issue of Sites provides a number of examples that illustrate how things 'do cultural work' in social life. It is therefore part of an increasing realisation in the social sciences and humanities that overt examinations of materiality and materialisation matter as much now as ever before.

We therefore hope that not only will the individual essays presented here be intriguing and useful to specialists in the respective areas but also that the volume as a whole will be a valuable heuristic tool for approaching issues of material culture in the Pacific. As well as surveying a range of current scholarship in the field of antipodean material culture studies, we trust that this special issue will provide some challenges and impetus for developing the next stage of research about matter in - and out - of place.

\section{Patrick Laviolette \& Bronwyn Labrum (Guest Editors)}

\section{ACKNOWLEDGEMENTS}

In addition to all our contributors and book reviewers, we would like to extend our sincerest thanks to Ruth Fitzgerald and Cyril Schafer, as well as the following for their diligent and enthusiastic involvement with this collection: Mark Busse, Nancy de Freitas, Haidy Geismar, Yoshi Ota, Mike Poltorak, Chris Wright and Jeff Sissons. 


\section{REFERENCES}

Anderson, Benedict 1983 Imagined Communities. London: Verso.

Bachelard, Gaston [1942]1983 [L'eau et les rêves: essay sur l'imagination de la matière]. Water and Dreams: An Essay on the Imagination of Matter (trans. E.R. Farrell). Dallas: Pegasus Foundation.

Bergson, Henri 1911 Matter and Memory (trans. Paul \& Palmer). New York: Zone Books.

Burns, Carol and Andrea Kahn (eds) 2005 Site Matters: Design Concepts, Histories, and Strategies. London: Routledge.

Douglas, Mary 1966 Purity and Danger: An Analysis of the Concepts of Pollution and Taboo. London: Routledge \& K.Paul.

Friedman, Jonathan 1994 Cultural Identity and Global Process. London: Sage.

Graves-Brown, Paul (ed) 2000 Matter, Materiality and Modern Culture. London: Routledge.

Hutton, John H. 1944 The place of material culture in the study of anthropology. The Journal of the Royal Anthropological Institute. 74 (1/2):1-6.

Ingold, Tim 2000 The Perception of the Environment: Essays on Livelihood, Dwelling and Skill. London: Routledge.

Miller, Daniel (ed) 1998 Material Cultures: Why Some Things Matter. Chicago: Univ. Press.

Mintz, Sidney, W. 2000 Sows' ears and silver linings. A backward look at ethnography. Current Anthropology. 41(2):168-89.

Pearce, Susan 1995 (ed), On Collecting: An Investigation into Collecting in the European Tradition. London: Routledge.

Prown, Jules 1982 Mind in matter: An introduction to material culture theory and method. Winterthur Portfolio. 17:1-19.

Russell, Bertrand 1927 The Analysis of Matter. London: Kegan Paul. 